\title{
Mineralogical and pore structure of organic-rich deltaic shales and sub-bituminous coals from early Maastrichtian Mamu Formation, Anambra Basin, Nigeria
}

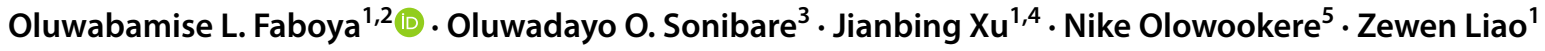

Received: 8 August 2020 / Accepted: 17 November 2020 / Published online: 23 November 2020

(c) Springer Nature Switzerland AG 2020

\begin{abstract}
The Mamu Formation source rocks in the Anambra Basin are targets for shale gas reservoir. However, fundamental data on the critical pore structures for assessing the shale reservoir capabilities are lacking. In this study, the source rocks were investigated for their mineralogical compositions and pore structure characteristics by X-ray diffraction, accelerated surface area and porosimetry and field emission scanning electron microscopy (FE-SEM). The bulk mineralogy of the samples is dominated by kaolinite and quartz with average percentage composition of 52.0 and 41.5, respectively, suggesting that the rocks are potential candidates for fracking. The total average pore volume and specific surface area in the samples are $0.0421 \mathrm{~cm}^{3} / \mathrm{g}$ and $22.43 \mathrm{~m}^{2} / \mathrm{g}$, respectively. The shale samples show higher amounts of total pore volumes relative to the sub-bituminous coals. No obvious organic pore is observed in the shale samples, but some inherited primary organic matter pores of plant origin exist in the sub-bituminous coals. Therefore, inorganic minerals pores are the major contributors to the pore development in the immature shales. The FE-SEM results reveal that the pore network in the shales is dominated by intraparticle pores and fractures. The observed well-developed fractures within the Mamu shales that may have resulted from tectonic events are capable of positively influencing the petrophysical properties of shales in the basin and by extension assist in shale gas exploration and development in the entire Lower Benue Trough.
\end{abstract}

Keywords Mamu Formation · Organic-rich shales · Mineralogy · Pore structure $\cdot$ Shale gas

\section{Introduction}

The understanding of the petrophysical properties such as the porosity, permeability, mineralogy, specific surface area and pore volume of shales, especially the nanopore arrangement is significant in characterising the shale pore structure [1-5] and in providing a practical implication when evaluating the adsorption, desorption, diffusion and gas flow in shales $[1,6]$. Shales are complex in nature with heterogeneous porous media [2]; thus, the complex pore network of shale is constrained by several geologic features such as the sedimentary processes, tectonic $[7,8]$, mineralogy, total organic carbon (TOC) content, thermal maturity [9] and organic matter type $[3,10]$.

Unlike the conventional hydrocarbon system, the shale gas reservoir is a steady self-contained source-reservoir petroleum system [2], with the nanometre-scale pore system significantly controlling the shale gas storage capacities [11]. Based on the classification published by the International Union of Pure and Applied Chemistry

$\triangle$ Zewen Liao, liaozw@gig.ac.cn | ${ }^{1}$ State Key Laboratory of Organic Geochemistry, Guangzhou Institute of Geochemistry, Chinese Academy of Sciences, Guangzhou 510640, Guangdong, China. ${ }^{2}$ Department of Chemical Sciences, Afe Babalola University, Ado-Ekiti, Ekiti-State, Nigeria. ${ }^{3}$ Department of Chemistry, University of Ibadan, Ibadan, Nigeria. ${ }^{4}$ State Key Laboratory of Nuclear Resources and Environment, East China University of Technology, Nanchang 30013, China. ${ }^{5}$ Department of Geology, Afe Babalola University, Ado-Ekiti, Ekiti-State, Nigeria. 
(IUPAC) [12], pores in shale can be categorised into 3 based on their sizes: micropores (pore width $<2 \mathrm{~nm}$ ), mesopores (pore width between 2 and $50 \mathrm{~nm}$ ) and macropores (pore width $>50 \mathrm{~nm}$ ). While taking into account of the different pore types, 3 divisions have been made, namely interparticle (interP) pores, intraparticle (intraP) pores and organic matter pores [4]. Shale gas could be derived from biogenic and/or thermogenic process $[13,14]$ and in situ accumulated as adsorbed dry gas in the fine micropores and mesopores of the organic matter and clays and also as free gas in the crevices and macropores $[9,13,14]$.

The Mamu Formation in the Anambra Basin contains organic matter with confirmed hydrocarbon generation potential [15-17]. The formation is composed of alternating shales, sandstones and coal seams [18]. The lower parts of the formation consist of several intervals of shale coexisting with coal, particularly in the middle section of the basin where its depth attains over $300 \mathrm{~m}$ [18], thereby positioning the formation as hot spot for possible unconventional shale gas generation. Studies on Mamu Formation have been limited to paleoenvironmental [16, 18-21] and hydrocarbons generative studies [15-17, 22].

As the demand for clean energy source increases, the Mamu Formation remains a target for shale gas resource. However, fundamental data on the pore structure of its source rock are practically not available and these are significant in resource potential evaluation [23]. The occurrence of shale gas depends mainly on the distribution and connectivity of pores for accumulating and forming the flow path network for gas flow [6]. As shales are combinations of minerals and organic-rich rock, the mineralogical compositions also play a major role in controlling the economics of shale gas plays. The different mineral compositions influence the different microscopic pore characteristics of shales [24]. This in turn is controlled by the different depositional environments. Marine shales are considered to be relatively enriched with higher amounts of brittle minerals as compared to shales deposited in lacustrine and fluvial environments [25]. The present study was conducted to investigate the mineralogical compositions, pore characteristics and factors controlling the pores development in the early Maastrichtian Mamu Formation, Anambra Basin. This work is expected to provide useful information and implications for fracturing, pores networks and shale gas potential of organic-rich source rocks in Mamu Formation.

\section{Geological background}

The geologic and stratigraphic settings of the Anambra basin have been adequately described in the literatures $[15,16,26,27]$. The basin traverses an area of about
$40,000 \mathrm{~km}^{2}$ with roughly $6000 \mathrm{~m}$ thick Cretaceous and Tertiary sediments. The Anambra Basin was formed during the Santonian tectonism that affected the entire Benue Trough [28] (Fig. 1). The event was marked with folding, faulting, volcanic extrusion, uplift and exhumation of pre-Santonian sedimentary fill [29]. The Anambra Basin is adjoined to the west by the Precambrian basement complex rocks of the western Nigeria, while Southern Benue Trough and Niger Delta basins restricted it to the east and
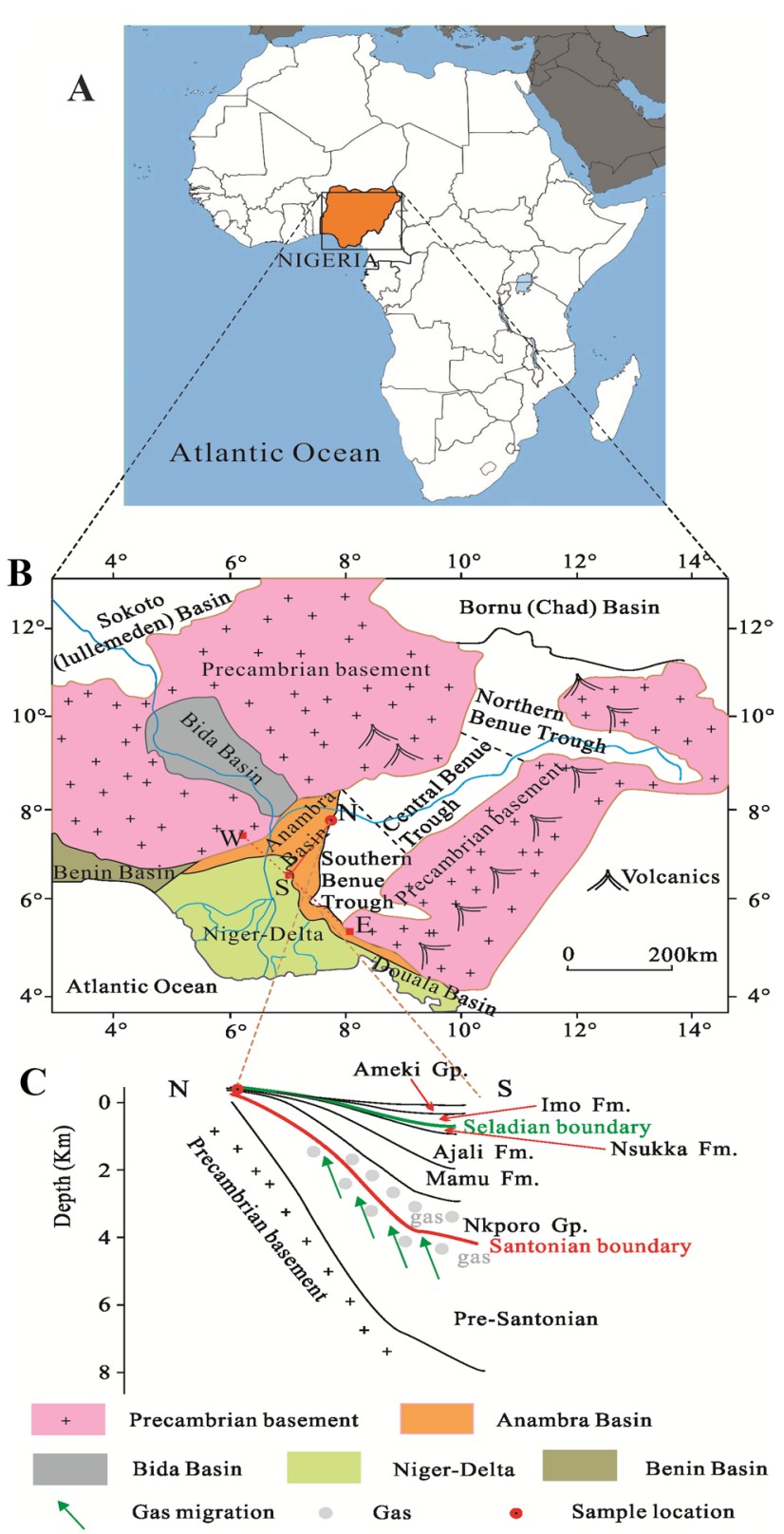

Fig. 1 a Map showing the location of Nigeria within African. $\mathbf{b}$ map of Nigeria indicating areas covered by sedimentary basins and basement rocks. $\mathrm{c}$ the $\mathrm{N}-\mathrm{S}$ cross section of the Anambra Basin, indicating the location of the sampled bole hole and its lithostratigraphy modified from [20] 
south, respectively (Fig. 1). Sedimentation began in the basin during the transgressive cycle (Campanian-Maastrichtian) and invariably led to the deposition of the oldest formation (Enugu/Nkporo shales) in the late Campanian. The Early Maastrichtian Mamu Formation overlies the Enugu/Nkporo shale with alternating sandstones, mudstones and shales. This unit also consists of coal seams in the lower parts of the formation at several intervals [18]. The Middle Maastrichtian Ajali Sandstone overlies the Mamu Formation and consists of unconsolidated coarseand fine-grained siltstone and weakly cemented mudstone $[26,27]$. The Ajali sandstone is overlain by Nsukka Formation, which is also referred to as upper coal measure dated Maastrichtian-Danian [26, 30]. The Imo shale (Paleocene) comprising shale with intermittent ironstone and thin sandstone overlies the Nsukka Formation [26, 27, 31]. The youngest strata in the basin are the Ameki Group (Eocene) consisting sandstones, shale, limestone, ironstone and siltstones [30, 32].

\section{Materials and methods}

\subsection{Samples}

Twelve core source rocks samples obtained from shallow boreholes ONP1 $\left(7^{\circ} 27^{\prime} 39.0^{\prime \prime} \mathrm{N}, 7.45^{\prime} 27.0^{\prime \prime} \mathrm{E}\right)$ and ONP4 $\left(7^{\circ} 27^{\prime} 13.9^{\prime \prime} \mathrm{N}, 7^{\circ} 45^{\prime} 53.5^{\prime \prime}\right.$ E) situated at Onupi, Kogi State, Nigeria (Fig. 1) were collected from depths ranging from 7.65 to $50.5 \mathrm{~m}$. The samples were taken from the Mamu Formation (Early Maastrichtian) in the Anambra Basin. The basic geochemical characteristics of the source rocks have been earlier described [17]. The TOC ranges from 1.30 to $7.37,14.87$ to 24.61 and 57.71 to $58.28 \%$ for shale, carbonaceous shale and sub-bituminous coal, respectively. The shale and carbonaceous shale/sub-bituminous coal contain organic matter Type II/III and Type III, respectively. The samples are immature with an average Tmax of $419^{\circ} \mathrm{C}$. The study location and the lithostratigraphy of Anambra Basin are shown in Fig. 1. The generalised stratigraphic chat of the Lower Benue Trough showing the basin and the lithologies of the sampled boreholes is illustrated in Fig. 2.

\subsection{Mineral composition and petrophysical analyses}

Each sample was pulverized (200 mesh) and oven dried at $80^{\circ} \mathrm{C}$ prior to mineral analysis. The mineral analysis was performed using a Bruker D8 Advance X-ray diffractometer with Cu ka radiation ( $\lambda=1.54066$ used for CuKa1) operated at $40 \mathrm{kV}$ and $30 \mathrm{~mA}$ and scanned step-wisely at $4^{\circ} \mathrm{min}^{-1}$ from $3^{\circ}$ to $85^{\circ}(2 \Theta)$. The relative percentage compositions of the minerals were determined semi-quantitatively by employing area under the curve for the main peaks of every mineral, with adjustment for Lorentz polarization [33]. The instrument's analytical precision for the results was $\pm 3 \%$.

Prior to the pore-sizes distribution (PSD) analysis of the rock samples, an approximately $3 \mathrm{~g}$ of each rock sample was crushed to 60-120 mesh. The samples were dried at $80^{\circ} \mathrm{C}$ and degassed under high vacuum until constant weights were obtained for at least $24 \mathrm{~h}$ using a degassing system. Briefly, the PSD was determined using liquid nitrogen $\left(\mathrm{N}_{2}\right)$ at $-195.8{ }^{\circ} \mathrm{C}$ and carbon dioxide $\left(\mathrm{CO}_{2}\right)$ at $0{ }^{\circ} \mathrm{C}$ by employing a micromeritics ASAP 2460 instrument. The glass tube enclosing the degassed rock samples were then lowered into $-195.8^{\circ} \mathrm{C}$ liquid nitrogen Dewar. The $\mathrm{N}_{2}$ adsorption measurements of the rock samples at different relative pressures were performed using $\mathrm{N}_{2}$ (purity $=99.999 \%$ ) as the adsorbate. The equilibrium intervals were $30 \mathrm{~s}$ and $45 \mathrm{~s}$ for $\mathrm{N}_{2}$ and $\mathrm{CO}_{2}$, respectively. The free spaces were examined independently and inputted manually during the $\mathrm{CO}_{2}$ adsorption measurements [34]. The instrument automatically merged the $\mathrm{N}_{2}$ and $\mathrm{CO}_{2}$ adsorption isotherms.

The FE-SEM imaging of the nanopores was achieved on sample chips after being treated with argon ion-beam milling (IM4000, Hitachi High-Tech). The topographic variation was documented using secondary electron (SE) images, while backscattered electron (BSE) images were used to delineate the compositional variation using both the Hitachi S4800 and Field Electron and Ion Company Helios NanoLab ${ }^{\mathrm{TM}} 600$ systems [24].

\section{Results and discussion}

\subsection{Mineralogical composition}

The mineral compositions of the source rocks are listed in Table 1. The Mamu rock samples consist mainly of kaolinite and quartz minerals. The kaolinite and quartz contents vary from 23.7 to $80.9 \%$ (av. $52 \%$ ) and 17.3 to $76.3 \%$ (av. $41.5 \%$ ), respectively. The amount of other minerals present are generally low and include feldspar, illite and pyrite with values ranging from 0 to $11.9 \%$ (av. $4.5 \%$ ), 0 to $6.6 \%$ (av. $0.9 \%$ ), and 0 to $4.4 \%$ (av. $0.6 \%$ ), respectively. The low amount of illite may indicate lower conversion of the clay minerals to illite form due to shallow burial [36]. The presence of kaolinite as predominant clay in the rocks (Table 1) indicates intensive chemical weathering process, which corresponds to the tropical conditions prevailing in the area that resulted in excessive leaching $[20,37]$. This idea is supported by Maastrichtian paleoclimatic reconstruction $[20,38]$ that grouped Nigeria (including Anambra Basin) within the tropical climate zone. 
A

\begin{tabular}{|c|c|}
\hline Age & Lower Benue \\
\hline Quarternary & \multirow{3}{*}{ Agbada } \\
\hline Pliocene & \\
\hline Miocene & \\
\hline Oligocene & 品 \\
\hline Eocene & $\bar{z}$ \\
\hline Paleocene & \begin{tabular}{|c|c|} 
& $\begin{array}{c}\text { Ameki / Imo } \\
\text { Nsukka }\end{array}$ \\
\end{tabular} \\
\hline Maastrichtian & $\sum_{<}^{\infty} \frac{2}{4}$ \\
\hline Campanian & \begin{tabular}{|l|l|}
$<$ & $\begin{array}{l}\text { Nkporol } \\
\text { Enuau }\end{array}$ \\
\end{tabular} \\
\hline Santonian & \\
\hline Coniacian & \multirow{2}{*}{ Nkalagu } \\
\hline Turonian & \\
\hline Cenomanian & 总 \\
\hline Albian & $\begin{array}{c}\text { Asu River Mtamosing } \\
\text { Group Abakaliki }\end{array}$ \\
\hline Pre - Albian & $\begin{array}{l}\text { Basement } \\
\text { complex }\end{array}$ \\
\hline
\end{tabular}

B

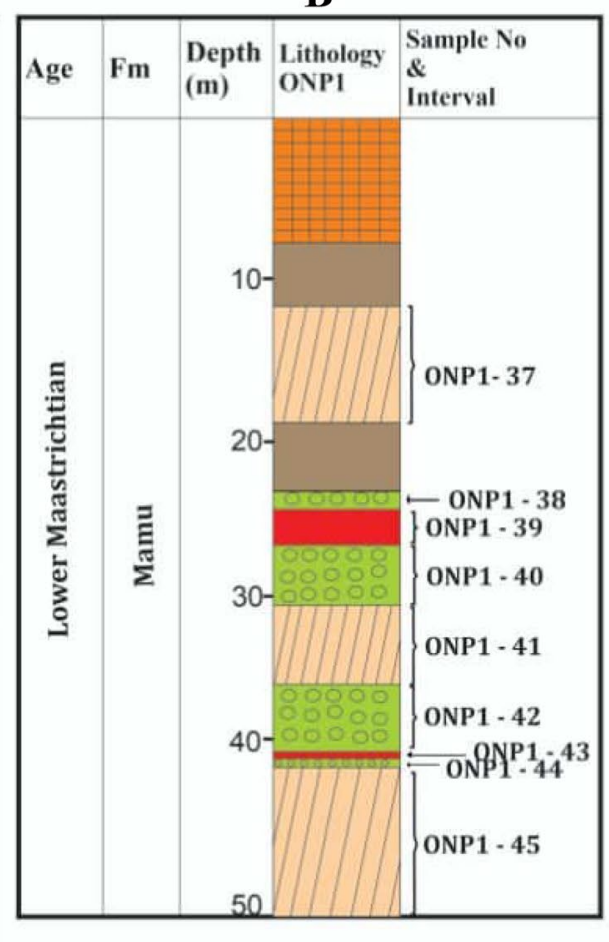

C

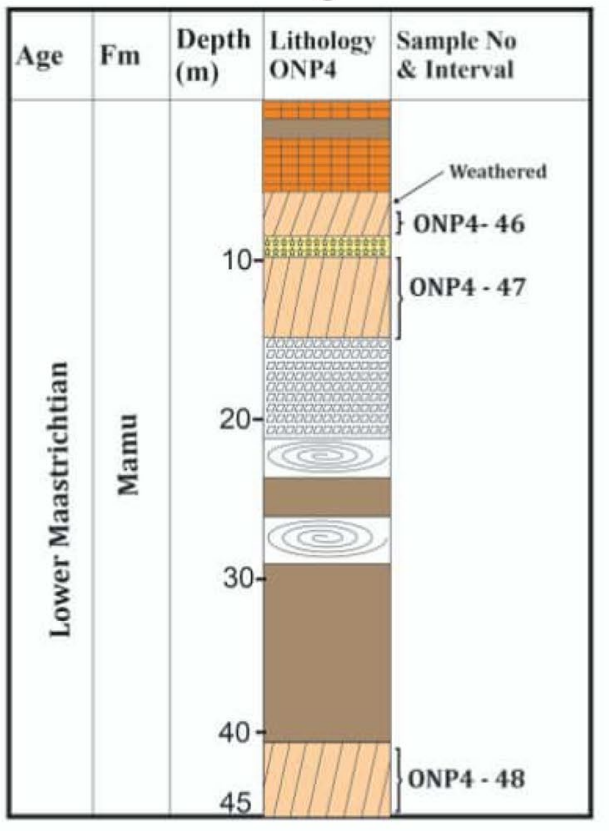

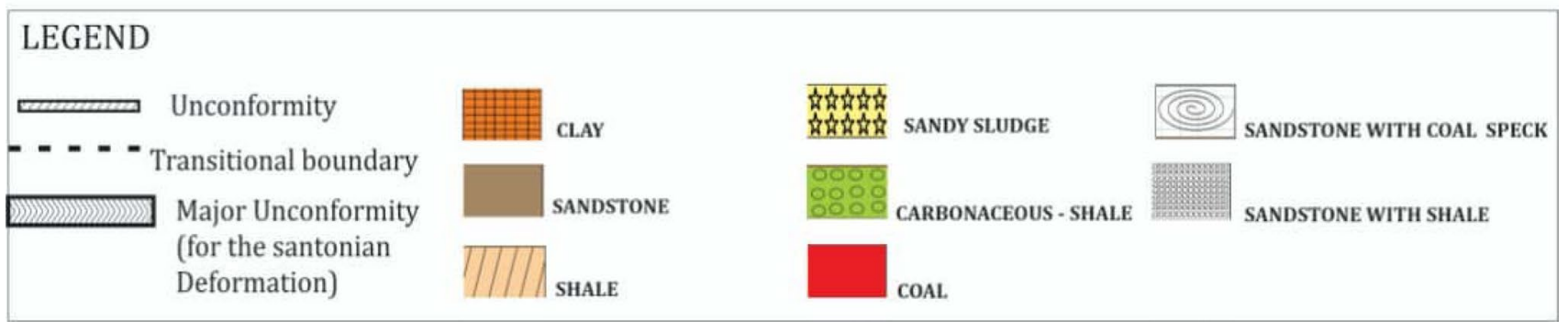

Fig. 2 a The generalised stratigraphic chat of the Lower Benue Trough showing Anambra Basin; b ONP1 and c ONP4 boreholes lithologies

The comparison of the mineralogical compositions of the source rock samples from the Mamu Formation with other shale gas reservoirs source rocks from the United States and China is depicted in Fig. 3. The mineral composition is similar to other shale gas reservoirs from the United States and China [39, 40]. The feldspar content in Mamu source rocks is comparable to that of Barnett shale, while the pyrite content is similar to that of Marcellus shale. Most of the samples are clay mineral (kaolinite)rich ( $>40 \%$ ), but also with relatively good amounts of quartz mineral ( $>30 \%$ ). The high clay mineral contents could reduce the effectiveness of fracturing. However, the appreciable amounts of brittle mineral (quartz) in the samples may negate this effect and preserve the brittleness for fracturing which is a significant factor for the development of shale gas $[8,41]$. The clay-rich source rocks in the Mamu Formation would also provide large surface areas that could positively influence the gas sorption capacity [42].

\subsection{FE-SEM observations and pore types}

The FE-SEM images for the immature shales and subbituminous coals are shown in Fig. 4. Fractures and intraparticle pore within the clay mineral platelets are the major pore types in the shale samples along with a few interparticle pores (Fig. $4 a-c$ ). No obvious organic matter pore is observed in the shale samples. However, the sub-bituminous coal samples display quite high amounts of organic matter domains and with associated inherited primary organic matter pores of vascular plant origin (illustrated with parallel lines and a cycle in Fig. $4 e-f$ ). These primary organic matter pores have been considered important in the distribution and morphology of pores even in late oil maturity to gas maturity samples [43]. Such primary organic pores have also been reported for immature marine Woodford shale in the United States (Ro $<0.35 \%)$ and marine-continental coals 
Table 1 Mineralogical compositions of source rock samples from Mamu Formation, Anambra Basin

\begin{tabular}{|c|c|c|c|c|c|c|c|c|}
\hline \multirow[t]{2}{*}{ Sample no./well } & \multirow[t]{2}{*}{ Depth (m) } & \multirow[t]{2}{*}{ Lithology } & \multicolumn{6}{|c|}{ Mineral composition (\%) } \\
\hline & & & Quartz & Kaolinite & Dolomite & Pyrite & Illite & Feldspar \\
\hline ONP1-37 & $11.5-19.0$ & Shale & 32.8 & 63.9 & 0 & 0 & 0 & 3.3 \\
\hline ONP1-38 & $22.75-23.08$ & Carbonaceous shale & 23.2 & 74.7 & 0 & 0 & 0 & 2.2 \\
\hline ONP1-39a & $23.08-25.41$ & Sub-bituminous coal & $51.8^{*}$ & $48.2^{*}$ & 0 & 0 & 0 & 0 \\
\hline ONP1-40 & $25.41-31.0$ & Carbonaceous shale & 31.3 & 66.3 & 2.4 & 0 & 0 & 0 \\
\hline ONP1-41 ${ }^{\mathrm{a}}$ & $31.0-37.0$ & Shale & 35.6 & 50.7 & 0 & 0 & 4.4 & 9.3 \\
\hline ONP1-42 & $37.0-41.5$ & Carbonaceous shale & 46.6 & 41.6 & 0 & 0 & 0 & 11.9 \\
\hline ONP1-43 & $41.5-41.62$ & Sub-bituminous coal & $76.3^{*}$ & $23.7^{*}$ & 0 & 0 & 0 & 0 \\
\hline ONP1-44 & $41.62-42.44$ & Carbonaceous shale & 30.5 & 66.6 & 0 & 0 & 0 & 2.9 \\
\hline ONP1-45 & $42.44-50.5$ & Shale & 17.3 & 80.9 & 0 & 0 & 0 & 1.8 \\
\hline ONP4-46 & $7.65-8.5$ & Shale & 51.4 & 33 & 0 & 4.4 & 0 & 11.2 \\
\hline ONP4-47 & $9.94-14.5$ & Shale & 61 & 33.1 & 0 & 2.9 & 0 & 3 \\
\hline ONP4-48 & $42.5-45.0$ & Shale & 40.6 & 41.1 & 0 & 0 & 6.6 & 8.8 \\
\hline Average & & & 41.5 & 52.0 & 0.2 & 0.6 & 0.9 & 4.5 \\
\hline
\end{tabular}

${ }^{a}$ Mineralogical data were cited from [35]. *Due to the high TOC content in the coal samples, great amounts of the amorphous fractions could not be precisely quantified. The minerals were heavily associated with the organics. Hence, values reported for quartz and kaolinite in Table 1, are indicative of the proportion of the 2 minerals in the coal samples

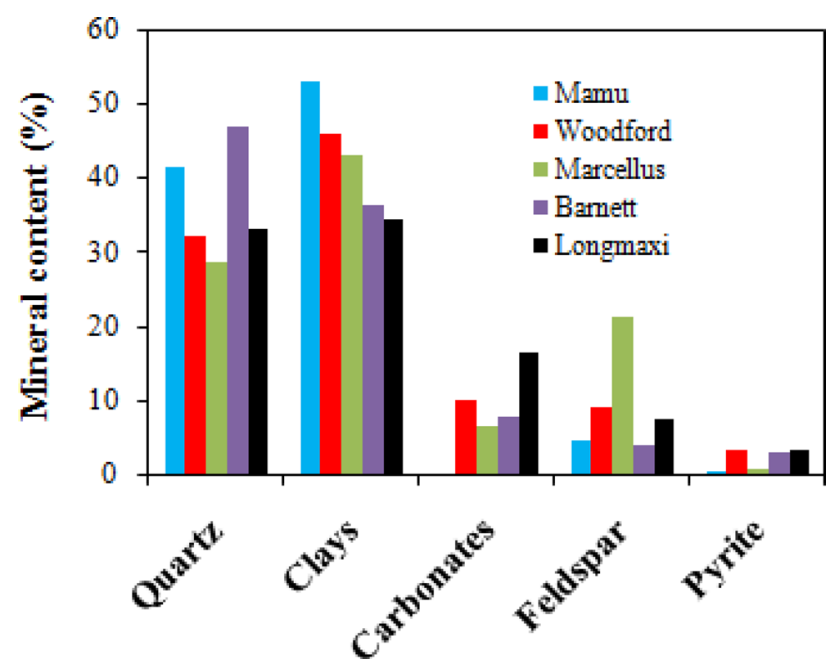

Fig. 3 Comparison of mineral composition of Mamu rock samples in Anambra Basin with shales from the United States and China

and Qinshui shale in China [43, 44]. The natural fractures observed in the immature shale samples [Fig. 4b, c] may have emanated from the effect of strong tectonic activities that pervaded the entire Benue Trough during the Santonian period that led to the development of the Anambra Basin [28] (Fig. 1). The plasticity nature of coal may have shielded it from cracking during the tectonic events and as such, no obvious fracture is observed in the sub-bituminous coal samples [Fig. 4].

\subsection{Pore characterisation of the samples}

\subsubsection{Gas adsorption characteristics}

The nitrogen adsorption and desorption isotherms for the Mamu source rocks are shown in Fig. 5. The curves generally show an increasing adsorption of nitrogen with increasing pressure in all the samples. All the samples demonstrate some level of adsorption at relative low pressure $(P / P o<0.01)$, signifying micropores existence $[45,46]$. A critical look at the hysteresis loops of the samples reveals that the samples have Type $\mathrm{H} 3$ with non-appearance of plateaus at relative high pressure $(P / P O>0.95)[47]$. This pattern of hysteresis loops has been linked to conglomeration of plate-shaped particles leading to slit-shaped pores $[45,47,48]$. The primary textural control of mudrock nanostructure had been attributed to clay hosted porosity [45]. Consequently, the high clay mineral (kaolinite) content as indicated by the XRD and FE-SEM analyses (Table 1; Fig. 4) in the Mamu shales and sub-bituminous coals might have spurred the slit-shaped pores observed in the adsorption-desorption isotherms. The $\mathrm{CO}_{2}$ adsorption isotherms for all the samples indicate Type I (Fig. 6a), confirming the existence of pores diameter less than $2 \mathrm{~nm}$ [47]. The capacity for adsorption by the samples generally increases with increasing relative pressure with most of the samples showing relatively strong adsorption capacity $\left(1.12-16.2 \mathrm{~cm}^{3} / \mathrm{g}\right.$ at a relative pressure $\left.P / P O=0.03\right)$ (Fig. 6a). The carbonaceous shale and sub-bituminous coal samples with higher TOC contents (TOC $>10 \%$ ) obviously indicate stronger adsorption capacity even at very low 

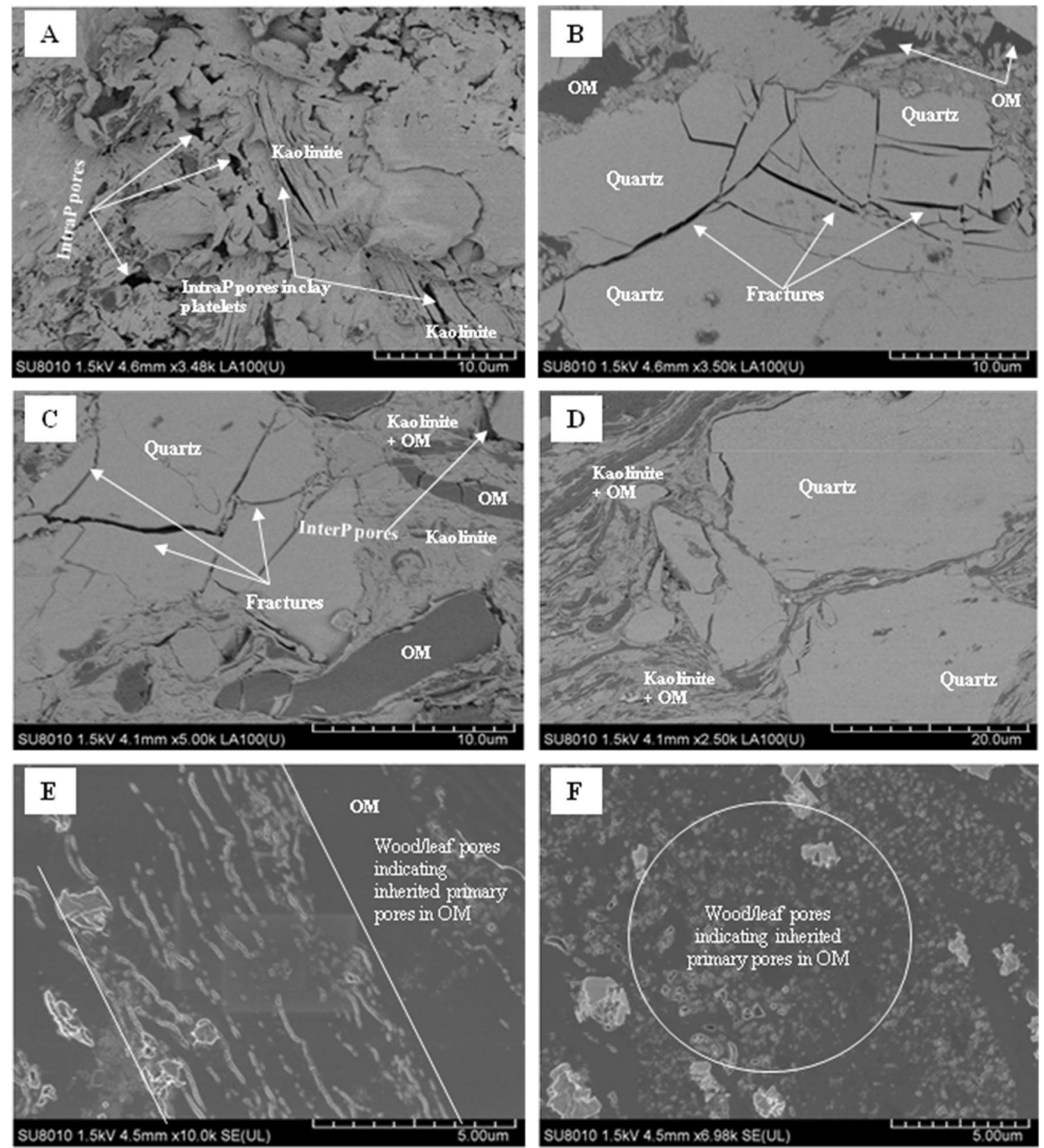

Fig. 4 Field emission scanning electron microscope (FE-SEM) image of representative shale (a and b); carbonaceous shale (c and $\mathbf{d}$ ); and sub-bituminous coal (e and $\mathbf{f}$ ) samples from Mamu Formation

relative pressure $(P / P 0<0.005)$, suggesting more micropores (Fig. $6 \mathrm{~A}$ ), than the shale samples having TOC $<10 \%$. A strong positive correlation $\left(R^{2}=0.947\right)$ exists between the average quantities of $\mathrm{CO}_{2}$ adsorbed and the total organic content in all the studies samples (Fig. 6b).

\subsubsection{Pore volume}

The nonlocal density functional theory (NLDFT) technique was employed to determine the pore parameters of the samples based on the $\mathrm{CO}_{2}$ and $\mathrm{N}_{2}$ composited adsorption. This method has proved to be more suitable for exploring a broad pore size range $(0.33-100 \mathrm{~nm})$ for organic-rich shale $[47,49]$. The values obtained for the pore parameters from the samples are presented in Table 2. The total average pore volume obtained for all the samples is $0.0421 \mathrm{~cm}^{3} / \mathrm{g}$. This value is reasonably higher than the values reported from shale gas reservoirs in both Rhuddianian (av. $0.0268 \mathrm{~cm}^{3} / \mathrm{g}$ ) and lower Aeronian (av. $0.0226 \mathrm{~cm}^{3} / \mathrm{g}$ ) sections of Longmaxi 

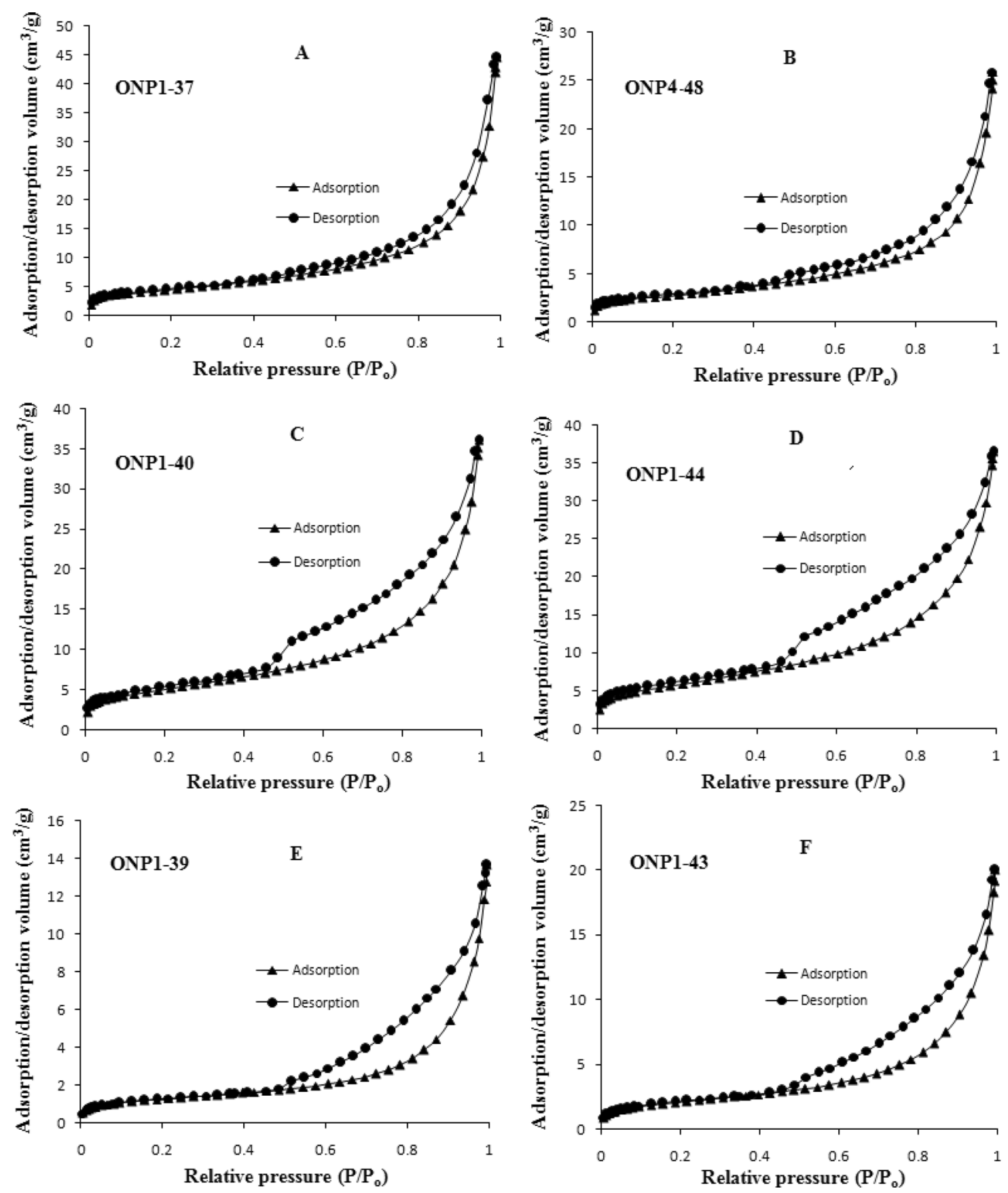

Fig. 5 Representative nitrogen adsorption-desorption isotherm for shale ( $\mathbf{a}$ and $\mathbf{b}$ ), carbonaceous shale (c and $\mathbf{d}$ ) and sub-bituminous coal (e and f) from Mamu Formation

Formation, in the Sanquan town, China [49]. The total average values of micropore, mesopore and macropore volumes in the samples are $0.0033 \mathrm{~cm}^{3} / \mathrm{g}, 0.0330 \mathrm{~cm}^{3} / \mathrm{g}$ and $0.0058 \mathrm{~cm}^{3} / \mathrm{g}$ (Table 2) amounting to $7.6 \%, 78.3 \%$ and $13.6 \%$ of the total pore volumes, respectively. This shows that over $70 \%$ of the micropores-macropores volume in the Mamu source rocks is contained within the mesopores, with little contributions from micropores and macropores. The total pore volume of the shale, carbonaceous shale and sub-bituminous coal ranges from 0.0245 to $0.0806 \mathrm{~cm}^{3} / \mathrm{g}$ (av. $0.0455 \mathrm{~cm}^{3} / \mathrm{g}$ ), 0.0259 to $0.0553 \mathrm{~cm}^{3} / \mathrm{g}$ (av. $0.0464 \mathrm{~cm}^{3} / \mathrm{g}$ ), and 0.0181 to $0.028 \mathrm{~cm}^{3} / \mathrm{g}$ (av. $0.0231 \mathrm{~cm}^{3} / \mathrm{g}$ ), respectively. This clearly shows that the average values of the total pore volume of the shales samples are comparatively higher than that of the sub-bituminous coal. 

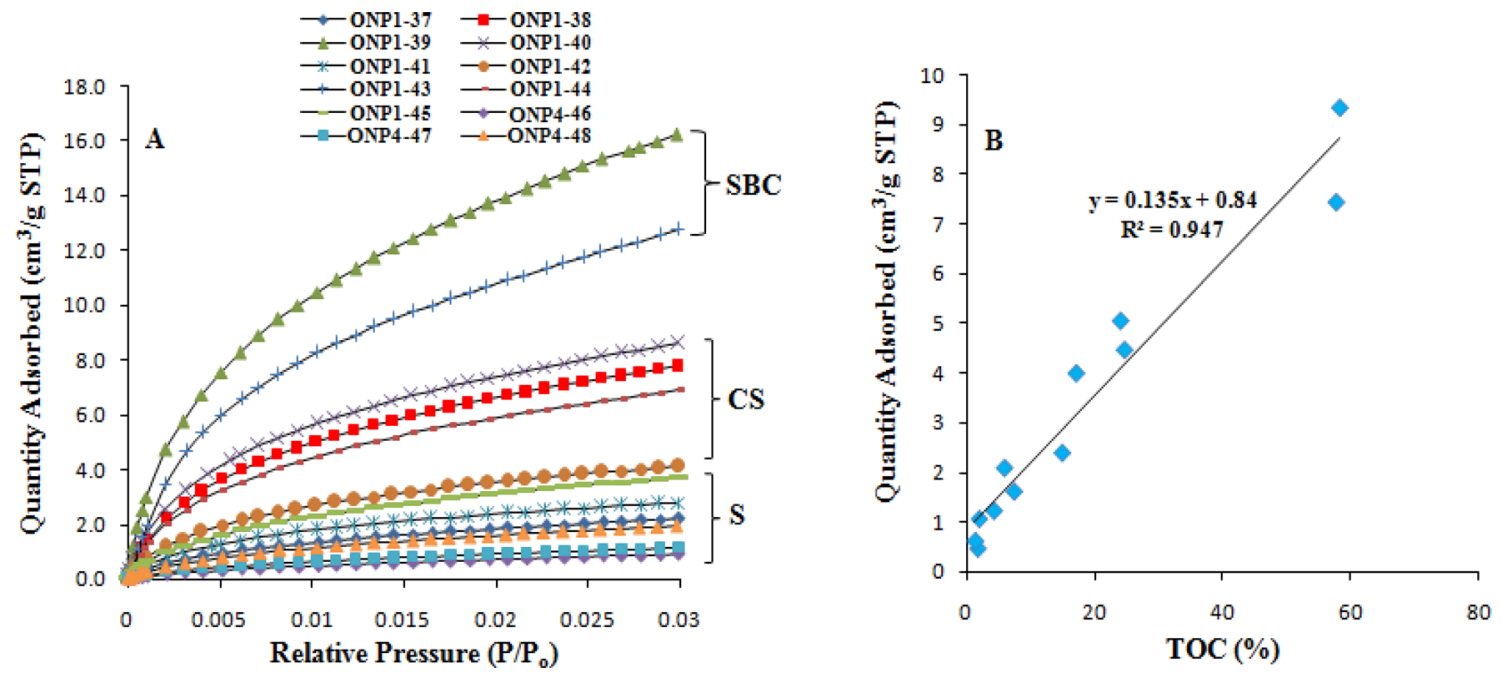

Fig. 6 a Low-pressure $\mathrm{CO}_{2}$ adsorption isotherms of the samples and $\mathbf{b}$ relationship between $\mathrm{CO}_{2}$ quantities adsorbed and TOC (SBC Subbituminous coal; CS Carbonaceous shale; S Shale)

Table 2 Pore structure parameters obtained by the nonlocal density functional theory (NLDFT) method

\begin{tabular}{|c|c|c|c|c|c|c|c|c|c|}
\hline \multicolumn{10}{|c|}{ Composited N2 and CO2 NLDFT model } \\
\hline \multirow[t]{2}{*}{ Lithology } & \multirow[t]{2}{*}{ Sample No } & \multicolumn{4}{|c|}{ Pore volume $\left(\mathrm{cm}^{3} / \mathrm{g}\right)$} & \multicolumn{4}{|c|}{ Pore specific surface area $\left(\mathrm{m}^{2} / \mathrm{g}\right)$} \\
\hline & & Micropore & Mesopore & Macropore & Total pore & Micropore & Mesopore & Macropore & Total pore \\
\hline \multirow[t]{6}{*}{ Shale } & ONP1-37 & 0.0021 & 0.0517 & 0.0092 & 0.0630 & 11.62 & 8.38 & 0.23 & 20.23 \\
\hline & ONP1-41 & 0.0017 & 0.0346 & 0.0071 & 0.0434 & 8.94 & 4.33 & 0.18 & 13.45 \\
\hline & ONP1-45 & 0.0046 & 0.0653 & 0.0107 & 0.0806 & 22.04 & 12.52 & 0.26 & 34.82 \\
\hline & ONP4-46 & 0.0006 & 0.0190 & 0.0049 & 0.0245 & 3.20 & 2.10 & 0.12 & 5.42 \\
\hline & ONP4-47 & 0.0007 & 0.0189 & 0.0050 & 0.0246 & 3.65 & 2.00 & 0.13 & 5.78 \\
\hline & ONP4-48 & 0.0016 & 0.0302 & 0.0051 & 0.0369 & 8.60 & 4.85 & 0.12 & 13.57 \\
\hline Average & & 0.0019 & 0.0366 & 0.0070 & 0.0455 & 9.68 & 5.70 & 0.17 & 15.55 \\
\hline \multirow[t]{4}{*}{ Carbonaceous shale } & ONP1-38 & 0.0044 & 0.0444 & 0.0065 & 0.0553 & 24.30 & 5.85 & 0.16 & 30.31 \\
\hline & ONP1-40 & 0.0059 & 0.0398 & 0.0058 & 0.0515 & 32.04 & 5.98 & 0.14 & 38.16 \\
\hline & ONP1-42 & 0.0017 & 0.0198 & 0.0044 & 0.0259 & 9.33 & 1.96 & 0.11 & 11.40 \\
\hline & ONP1-44 & 0.0056 & 0.0421 & 0.0051 & 0.0528 & 29.93 & 7.41 & 0.12 & 37.46 \\
\hline Average & & 0.0044 & 0.0365 & 0.0054 & 0.0464 & 23.90 & 5.30 & 0.13 & 29.33 \\
\hline \multirow[t]{2}{*}{ Sub-bituminous coal } & ONP1-39 & 0.0053 & 0.0106 & 0.0022 & 0.0181 & 28.66 & 0.91 & 0.05 & 29.62 \\
\hline & ONP1-43 & 0.0050 & 0.0195 & 0.0035 & 0.0280 & 26.85 & 2.04 & 0.08 & 28.97 \\
\hline Average & & 0.0052 & 0.0151 & 0.0029 & 0.0231 & 27.76 & 1.48 & 0.07 & 29.30 \\
\hline Total average & & 0.0033 & 0.0330 & 0.0058 & 0.0421 & 17.43 & 4.86 & 0.14 & 22.43 \\
\hline
\end{tabular}

It is instructive to note from the $\mathrm{N}_{2}$ adsorption isotherm (Fig. 7), that samples with higher TOC contents do not normally show stronger $\mathrm{N}_{2}$ adsorption capacity as observed from the $\mathrm{CO}_{2}$ adsorption isotherm (Fig. 6). For example, the shale sample ONP1-45 (TOC $=5.85 \%)$ has the highest $\mathrm{N}_{2}$ adsorption up to $56.45 \mathrm{~cm}^{3} / \mathrm{g}$ (Fig. 7A) as compared to the sub-bituminous coal sample ONP1-39 (TOC $=58.28 \%)$, that displays the lowest $\mathrm{N}_{2}$ adsorption capacity $\left(13.64 \mathrm{~cm}^{3} / \mathrm{g}\right.$ ) (Fig. 7B). This suggests that the micropores may be largely associated with organic matter in the samples while mineral compositions and fracture might be accountable for the larger pores.

\subsubsection{Pore specific surface area}

The total average specific surface area derived for the samples is $22.43 \mathrm{~m}^{2} / \mathrm{g}$. This value is relatively lower than the average value reported from Rhuddianian (av. $24.8 \mathrm{~m}^{2} / \mathrm{g}$ ), 

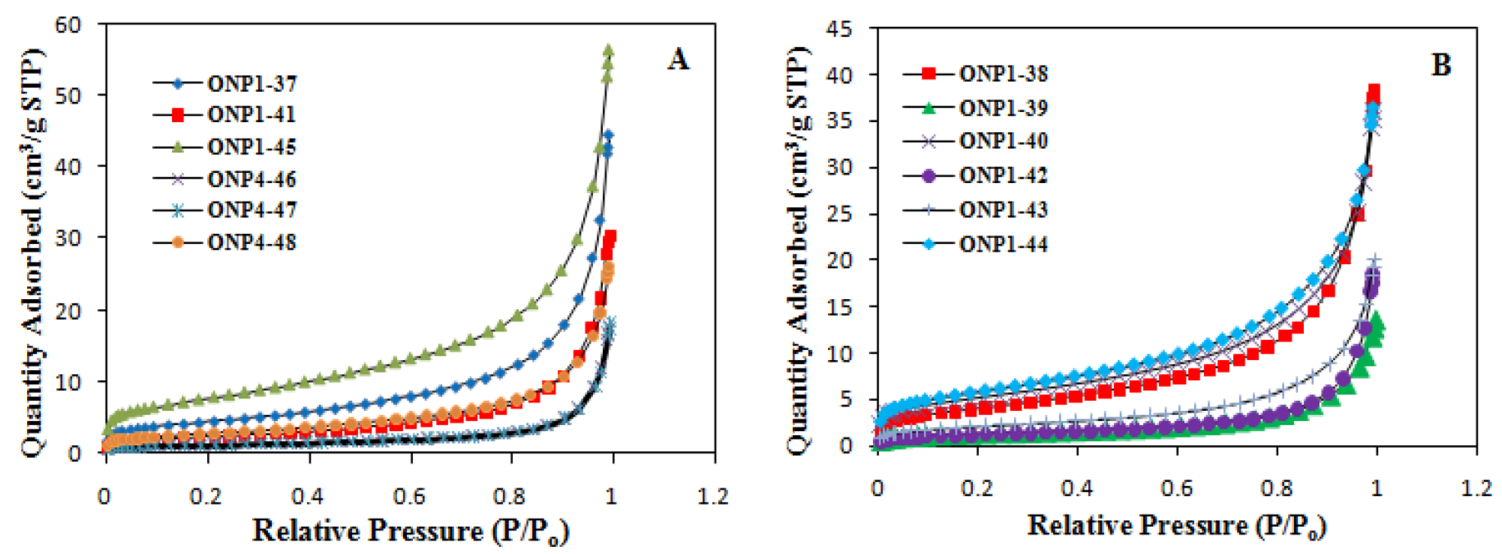

Fig. $7 N_{2}$ adsorption isotherms for a samples with TOC $<10 \%$ and $\mathbf{b}$ samples with TOC $>10 \%$

but higher than the average value from lower Aeronian (av. $18.5 \mathrm{~m}^{2} / \mathrm{g}$ ) sections of Longmaxi Formation, in the Sanquan town, China [49]. The total average values of micropore, mesopore and macropore specific surface areas in the samples are $17.43 \mathrm{~m}^{2} / \mathrm{g}, 4.86 \mathrm{~m}^{2} / \mathrm{g}$ and $0.14 \mathrm{~m}^{2} / \mathrm{g}$ (Table 2) amounting to $77.7 \%, 21.7 \%$ and $0.6 \%$ of the total pore specific surface areas, respectively. This implies that over $70 \%$ of the micropores-macropores surface area in the samples is enclosed within the micropores. The total pore specific surface area of the shale, carbonaceous shale and sub-bituminous coal range from 5.42 to $34.82 \mathrm{~m} 2 / \mathrm{g}$ (av. $15.55 \mathrm{~m}^{2} / \mathrm{g}$ ), 11.4 to $38.16 \mathrm{~m}^{2} / \mathrm{g}$ (av. $29.33 \mathrm{~m}^{2} / \mathrm{g}$ ), and 28.97 to $29.62 \mathrm{~m}^{2} / \mathrm{g}$ (av. $29.30 \mathrm{~m}^{2} / \mathrm{g}$ ), respectively. This clearly shows that carbonaceous shale and sub-bituminous coal have similar pore surface areas which almost double that of the shale, probably resulting from the large number of micropores in carbonaceous shale and sub-bituminous coal samples. In general, large pore surface areas observed for all the samples along with high amount of clay mineral (kaolinite) suggest excellent gas holding potential [46].

\subsection{Constraints on pore development}

\subsubsection{Constraint of TOC}

Previous authors have shown that pore development and porosity of shale gas reservoirs are controlled by the TOC content $[9,50]$. In the present study, the TOC content reveals a weak positive correlation with the pore structure parameters (specific surface areas and pore volumes) in the rock samples with TOC $<10 \%$ (Fig. $8 a-b$ ), but an obvious general negative relationship is observed with pore structure parameters in samples having TOC $>10 \%$ (Fig. $8 \mathrm{c}-\mathrm{d}$ ). It is believed that a more dominant factor such as the mineral content could play a more influential role in the pore system development of the samples. Pan et al. [45] have suggested that a fragile relationship exists between TOC contents and the pore structure parameters in source rocks having high clay mineral content. This may have resulted from compaction effects between the soft organic matter pores and clay minerals in the rocks during the burial [2]. However, the observed weak positive association between the pore structure parameters and TOC content in the shales with TOC $<10 \%$, shows that TOC contents remain a contributing factor in the nanopore development of immature shale in Mamu Formation.

\subsubsection{Constraint of minerals}

The plots between the pore volumes and pore specific surface areas of the samples with TOC $<10 \%$ (Fig. 9a and b), indicate a very strong correlation between the pore structure parameters and the clay mineral (kaolinite) with $R^{2}$ values greater than 0.9 (Fig. 9a and b). This suggests that clay mineral (kaolinite) strongly controlled the pore development of the source rocks samples from Mamu Formation. This is also true for samples with TOC $>10 \%$ where the influence of kaolinite on the pore structure parameters shows a positive correlation, except for the micropore pore volume and micropore specific surface area (Fig. 9 c and d).

In the contrary, quartz displays a strong negative relationship with pore structure parameters in all the studied samples (Fig. 10). This suggests the terrigenous origin of the quartz in the source rocks where pore development is hindered by secondary growth of pores that occur during diagenesis [46]. Therefore, inorganic minerals are the major contributing factors of pore development in immature deltaic source rocks in Mamu Formation.

\subsubsection{Constraint of fractures}

Tectonism may appreciably influences the pore type and pore structure evolution of organic-rich shale [8]. The 

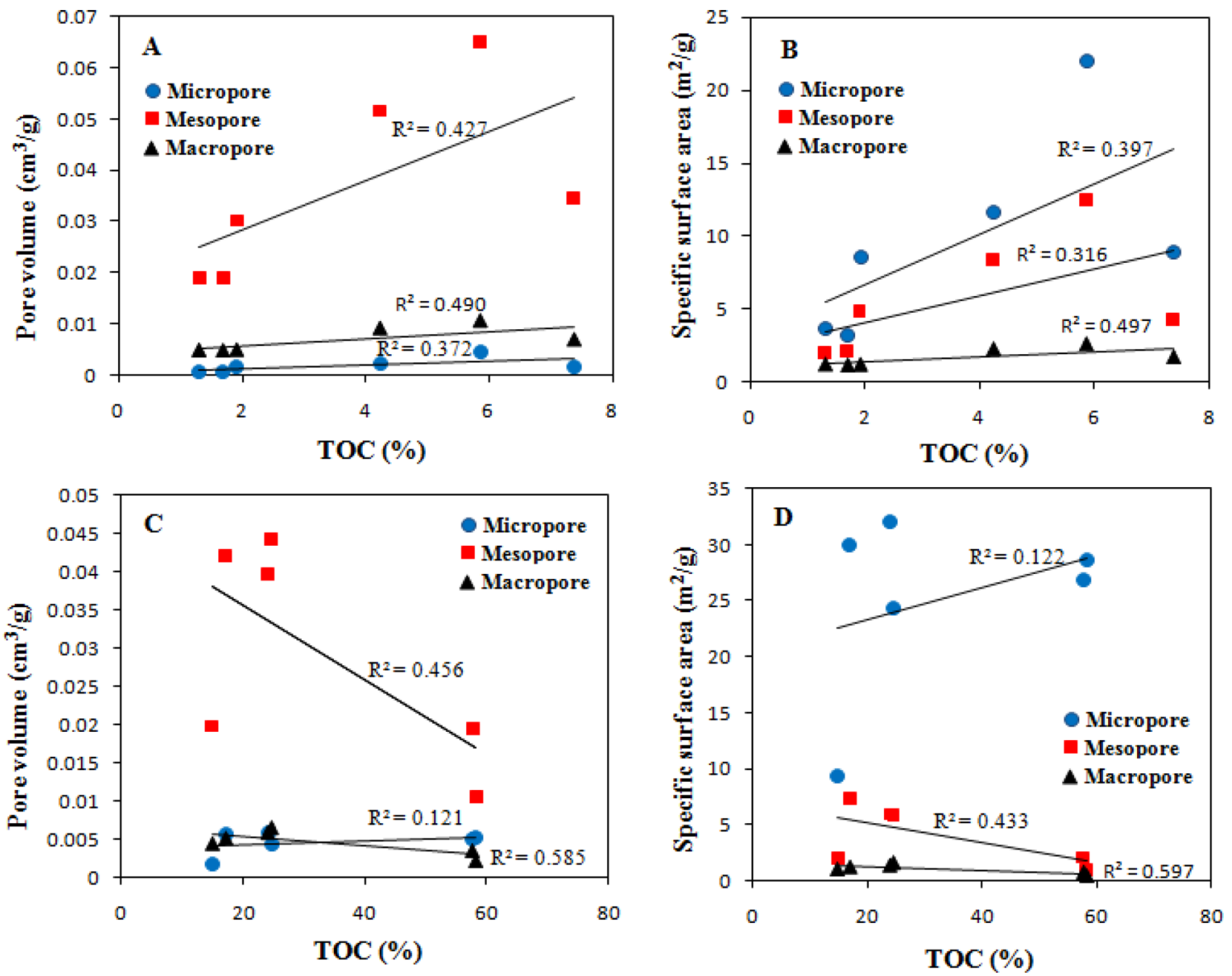

Fig. 8 Plots showing the relationship between the TOC content and pore structure parameters (pore volumes and specific surface areas) in rock samples with TOC $<10 \%$ (a and $\mathbf{b})$ and TOC $>10 \%$ (c

FE-SEM images indicate that fractures are well developed in the immature shales. This is believed to have resulted from tectonic movements. The mesopore and macropore volumes in the shale samples are significantly higher than the sub-bituminous coal (Table 2 ) and consequently with higher total pore volumes. This may partly be attributed to contributions from fractures which are non-existent in the sub-bituminous coal. Many authors had previously attributed the enhanced total pore volume to the increase in mesopores and macropores caused by the development of cracks and microcracks [49,50]. These pores and cracks could favour gas release from the shale matrix $[49,51]$, improve storage space [8], as well as capable of increasing the connectivity of the shale pore network and providing lateral migration conduits for shale gas on a regional scale [49]. Therefore, pore structure of shales in the basin may be largely influenced by fractures resulting from tectonic activities. and d). In Figs. 8-10, the macropore specific surface area values were multiplied by 10 for them to fall within the plot area

\subsubsection{Implications for shale gas accumulation and exploration}

Although, the samples under study are immature, the deeper parts of the formation contain mature source rocks [16], and more importantly, the more mature source rocks in the pre-Santonian (Cross River Group-Eze-Aku and Awgu Formations) successions of the Lower Benue Trough that are capable of generating oil and gas [15]. The gas generated could migrate up-dip through faults, fractures originated from the effect of strong tectonic activities and even along the Santonian boundary and store within the Mamu Formation due to the large storage space within its shale pore structure. The well-developed natural fractures would save shale gas developmental cost and water resource [7]. Thus, the Mamu Formation is a potential target for shale gas exploration and development for the entire Lower Benue Trough. 

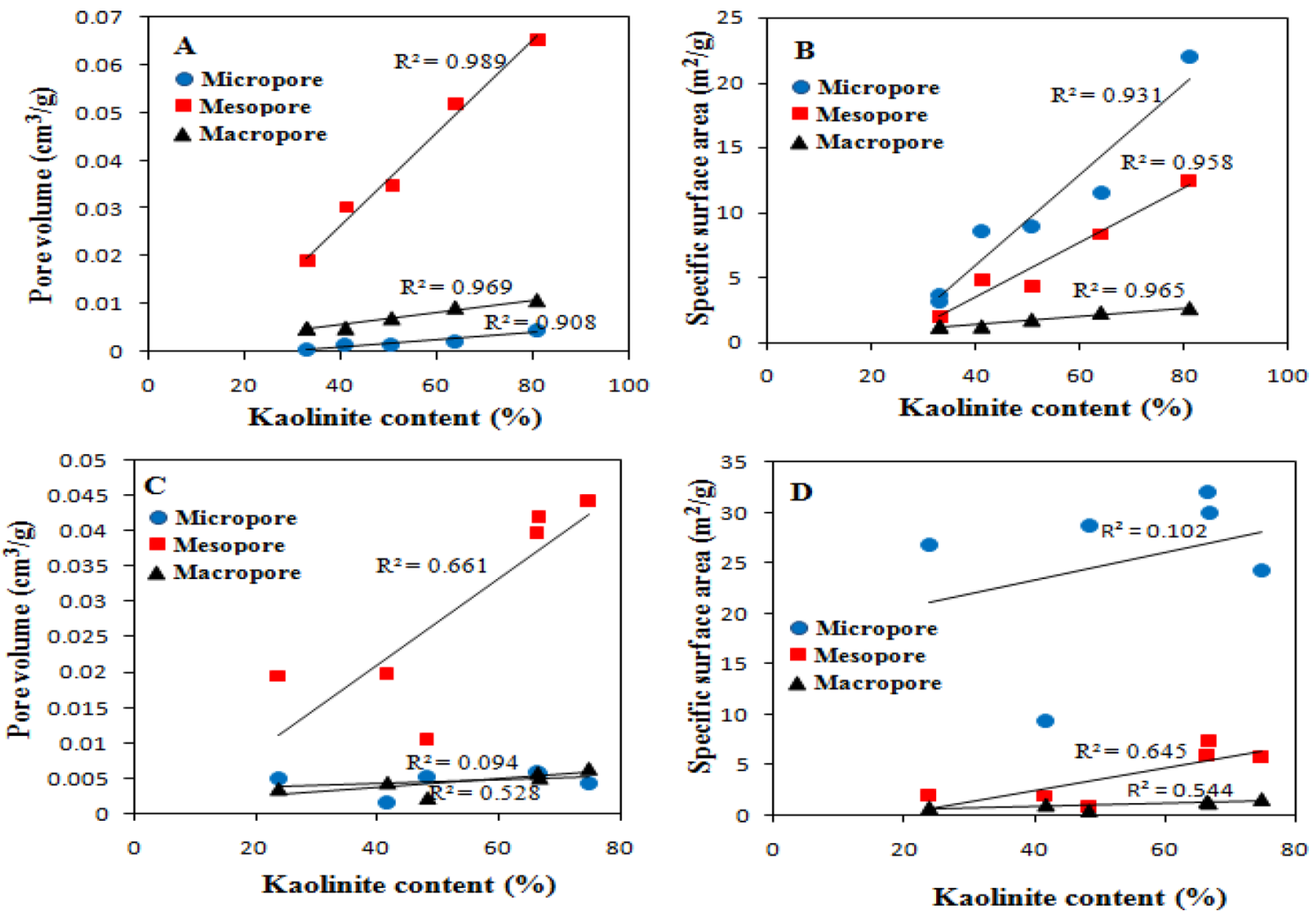

Fig. 9 Plots showing the relationship between the kaolinite content (\%) and pore structure parameters (pore volumes and specific surface areas) in samples with TOC $<10 \%$ (a and b) and TOC $>10 \%$ (c and d)

\section{Conclusions}

The reservoir quality of deltaic source rocks from the Mamu Formation in the Anambra Basin, Nigeria was investigated within the context of the mineralogical composition and pore structure characterisation. The bulk mineralogy of the samples is dominated by kaolinite and quartz. The clay-rich source rocks would provide large surface areas that could positively influence the gas sorption capacity, and the relatively high brittle mineral would be favourable to the hydraulic fracturing process. The pore volumes and specific surface areas in the samples are significantly related to the mineral compositions. The FE-SEM images indicate that inroganic mineral pores (intraP pores) and fractures are the dominant pore types in the immature shales. The well-developed fractures that may have originated from tectonic movements will greatly compensate for the intraP pores and improve connectivity, storage space and gas migration pathways in the basin. The pore distribution patterns obtained in this work are critical for further research in shale gas exploration and exploitation in this basin. Owing to the immature and limited numbers of studied samples, further works are required from mature sections in the Basin and by extension, other formations in the Lower Benue with proven potential for economic hydrocarbon accumulation to improve our present knowledge on the pore structural evolution of the source rock with increasing reservoir depths. 

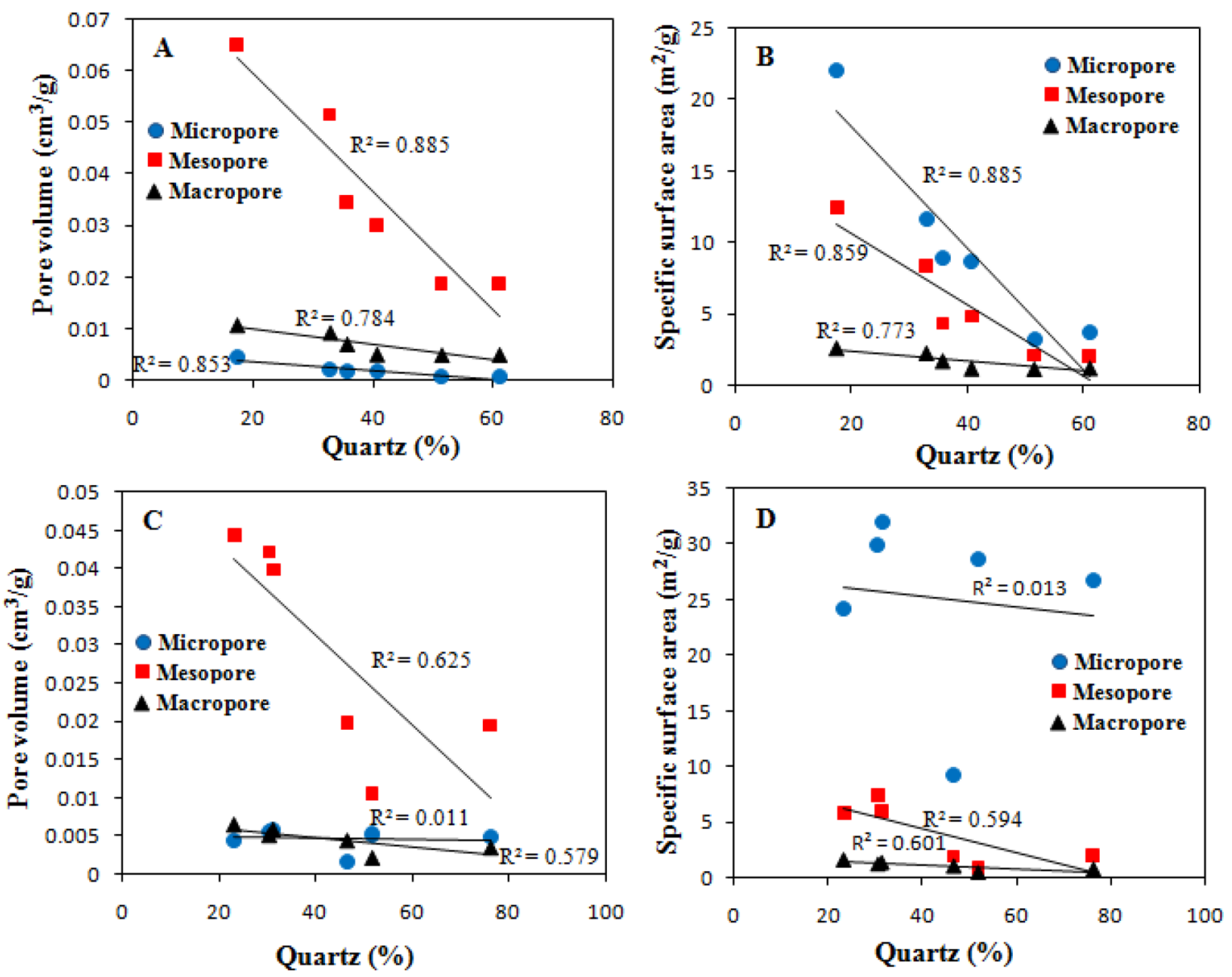

Fig.10 Plots showing the relationship between the quartz content (\%) and pore structure parameters (pore volumes and specific surface areas) in samples with TOC $<10 \%$ ( $\mathbf{a}$ and $\mathbf{b})$ and TOC $>10 \%$ (c and $\mathbf{d})$

Acknowledgements This work was supported by the CAS President's International Fellowship Initiative for Postdoctoral Researchers (grant no. 2018PM0058) and the National Natural Science Foundation of China (grant no. 41772117).

\section{Compliance with ethical standards}

Conflict of interest The authors declare that there is no conflict of interest.

\section{References}

1. Loucks RG, Reed RM, Ruppel SC, Jarvie DM (2009) Morphology, genesis, and distribution of nanometer-scale pores in siliceous mudstones of the Mississippian Barnett Shale. J Sedim Res 79:848-861

2. Wei Z, Wang Y, Wang G, Sun Z, Xu L (2018) Pore characterization of organic-rich late Permian Da-long formation shale in the Sichuan Basin, Southwestern China. Fuel 211:507-516

3. Milliken KL, Rudnicki M, Awwiller DN, Zhang T (2013) Organic matter-hosted pore system, Marcellus Formation (Devonian), Pennsylvania. AAPG Bull 97:177-200
4. Loucks RG, Reed RM, Ruppel SC, Hammes U (2012) Spectrum of pore types and networks in mudrocks and a descriptive classification for matrix related mudrock pores. AAPG Bull 96:1072-1092

5. Löhr SC, Baruch ET, Hall PA, Kennedy MJ (2015a) Is organic pore development in gas shales influenced by the primary porosity and structure of thermally immature organic matter? Org Geochem 87:119-132

6. Yang R, He S, Yi JZ, Hu QH (2016) Nano-scale pore structure and fractal dimension of organic-rich Wufeng-Longmaxi shale from Jiaoshiba area, Sichuan Basin: investigations using FESEM, gas adsorption and helium pycnometry. Mar Petrol Geol 84(70):27-45

7. Zhu H, Ju Y, Huang C, Han K, Qi Y, Shi M, Yu K, Feng H, Li W, Ju L, Qian J (2019) Pore structure variations across structural deformation of Silurian Longmaxi Shale: an example from the Chuandong thrust-fold Belt. Fuel 241:914-932

8. Zhu H, Ju Y, Qi Y, Huang C, Zhang L (2018) Impact of tectonism on pore type and pore structure evolution in organic-rich shale: implications for gas storage and migration pathways in naturally deformed rocks. Fuel 228:272-289

9. Xi Z, Tang S, Wang J, Yang G, Li L (2018) Formation and development of pore structure in marine-continental transitional shale from northern China across a maturation gradient: insights from gas adsorption and mercury intrusion. Int J Coal Geol 200:87-102 
10. Zhao JH, Jin ZK, Jin ZJ, Wen X, Geng YK (2017) Origin of authigenic quartz in organic-rich shales of the Wufeng and Longmaxi Formations in the Sichuan Basin, South China: implications for pore evolution. J Nat Gas Sci Eng 38:21-38

11. Ross DJ, Bustin RM (2009a) Investigating the use of sedimentary geochemical proxies for paleoenvironment interpretation of thermally mature organic-rich strata: examples from the Devonian-Mississippian Shales, Western Canadian Sedimentary Basin. Chem Geol 260:1-19

12. Sing KS, Everett DH, Haul RAW, Mouscou L, Pierotti RA, Rouquerol J, Siemieniewska T (1985a) Reporting physisorption data for gas/solid systems with special reference to the determination of surface area and porosity. Pure Appl Chem 57(4):603-619

13. Curtis JB (2002) Fractured shale-gas systems. AAPG Bull 86(11):1921-1938

14. Jarvie D, Hill R, Ruble T, Pollastro R (2007) Unconventional shalegas systems: the Mississippian Barnett Shale of north central Texas as one model for thermogenic shale-gas assessment. AAPG Bull 91:475-499

15. Akande SO, Egenhoff SO, Obaje NG, Ojo OJ, Adekeye OA, Erdtmann BD (2012) Hydrocarbon potential of Cretaceous sediments in the lower and middle Benue Trough, Nigeria: insights from new source rock facies evaluation. J Afr Earth Sci 64:34-47

16. Adebayo OF, Adegoke AK, Mustapha KA, Adeleye MA, Agbaji AO, Abidin NSZ (2018) Paleoenvironmental reconstruction and hydrocarbon potentials of upper Cretaceous sediments in the Anambra Basin, southeastern Nigeria. Int J Coal Geol 192:56-72

17. Faboya OL, Sonibare OO, Xu JB, Cheng B, Deng Q, We ZW, Olowookere A, Liao ZW (2019) Geochemical characterisation of lower Maastrichtian Mamu Formation kerogens Anambra Basin Nigeria. Ser Earth Environ Sci, IOP Conf. https://doi.org/10.1088/17551315/360/1/012015

18. Akande SO, Mücke A (1993) Depositional environment and diagenesis of carbonates at the Mamu/Nkporo Formation, Anambra Basin, Southern Nigeria. J Afr Earth Sci 17:445-456

19. Adedosu TA, Sonibare OO, Tuo J, Ekundayo O (2011) Aromatic hydrocarbons distribution in Nigerian coal and their geochemical significance. Energ Source Part A 33(2):145-155

20. Edegbai AJ, Schwarka L, Oboh-Ikuenobe FE (2019) CampanoMaastrichtian paleoenvironment, paleotectonics and sediment provenance of western Anambra Basin, Nigeria: multi-proxy evidences from the Mamu Formation. J Afr Earth Sci 156:203-239

21. Edegbai AJ, Schwarka L, Oboh-lkuenobe FE (2020) Nature of dispersed organic matter and paleoxygenation of the CampanoMaastrichtian dark mudstone unit, Benin flank, western Anambra Basin: implications for Maastrichtian Trans-Saharan seaway paleoceanographic. J Afr Earth Sci 162:103654

22. AdedosuTA, Sonibare OO, Ekundayo O, Tuo J (2010) Hydrocarbongenerative potential of coal and interbedded shale of Mamu Formation, Benue Trough, Nigeria. Petrol Sci Technol 28:412-427

23. Guo H, Ruliang He R, Jia W, Peng P, Yuhong Lei $Y$, Luo X, Wang X, Zhang L, Jiang C (2018) Pore characteristics of lacustrine shale within the oil window in the upper Triassic Yanchang Formation, Southeastern Ordos Basin, China. Mar Pet Geol 9:279-296

24. Wei MM, Zhang L, Xiong YQ, Li JH, Peng PA (2016) Nanopore structure characterization for organic-rich shale using the nonlocal-density functional theory by a combination of $\mathrm{N}_{2}$ and $\mathrm{CO}_{2}$ adsorption. Microp Mesop Mat 227:88-94

25. Kumar S, Das S, Bastia R, Ojha K (2017) Mineralogical and morphological characterization of older cambay shale from North cambay Basin. Implication for shale oil/gas development. Marine and Petroleum Geology, India. https://doi.org/10.1016/j.marpe tgeo.2018.07.020

26. Reyment RA (1965) Aspects of the geology of Nigeria. University Press, Ibadan, Nigeria, p 145
27. Kogbe CA (1989) The cretaceous and paleogene sediments of Southern Nigeria, Geology of Nigeria, 2nd edn. Rock View, Nigeria, pp 325-334

28. Benkhelil J (1989) The origin and evolution of the Cretaceous Benue Trough Nigeria. J Afr Earth Sci 8(2-4):251-282

29. Guiraud R, Bosworth W (1997) Senonian basin inversion and rejuvenation of rifting in Africa and Arabia: synthesis and implications to plate-scale tectonics. Tectonophys 282:39-82

30. Obi GC (2000) Depositional model for the Companian-Maastrichtian Anambra Basin, Southern Nigeria. Ph.D. Thesis, University of Nigeria, Nsukka, Nigeria, p 291

31. Nwajide CS, Reijers TJA (1996) Sequence architecture in outcrops: example from Anambra Basin, Nigeria. NAPE Bull 11:23-33

32. Arua I, Rao VR (1987) New stratigraphic data on the Eocene Ameki Formation, Southestern Nigeria. J Afr Earth Sci 6:391-397

33. Chalmers GRL, Bustin RM (2008) Lower Cretaceous gas shales in northeastern British Columbia, part I: geological controls on methane sorption capacity. Bull Can Pet Geol 56:1-21

34. Tian H, Pan L, Xiao XM, Wilkins RWT, Meng ZP, Huang BJ (2013) A preliminary study on the pore characterization of lower Silurian black shales in the Chuandong thrust fold belt, southwestern China using low pressure N2 adsorption and FE-SEM methods. Mar Pet Geol 48:8-19

35. Faboya OL, Sonibare OO, Abimade SF, Liao Z*, (2020) Shale gas prospect of different source rock types from Early Maastrichtian Mamu Formation Anambra Basin, Nigeria, IOP Conf. Series: Earth and Environmental Science. Accepted

36. Varma AK, Panda S (2010) Role of clay minerals in shale gas exploration-an evaluation. In: Varma AK, Dubey RK, Sarkar BC, Saxena VK (eds) Geological and technological facets of CBM, Shale gas, energy resources and $\mathrm{CO}_{2}$ sequestration. Allied Publishers Private Limited, New Delhi, pp 99-107

37. Singer A (1984) The paleoclimatic interpretation of clay minerals in sediments-a review. Earth Sci Rev 21:251-293

38. Hay WW, Floegel S (2012) New thoughts about the Cretaceous climate and oceans. Earth Sci Rev 115:262-272

39. Chalmers GR, Bustin RM, Power IM (2012) Characterization of gas shale pore systems by porosimetry, pycnometry, surface area, and field emission scanning electron microscopy/transmission electron microscopy image analyses: examples from the Barnett, Woodford, Haynesville, Marcellus, and Doig units. AAPG Bull 96(6):1099-1119

40. Wei C, Qin G, Guo W, Yan B, Killough J (2013) Characterization and analysis on petrophysical parameters of a marine shale gas reservoir. Paper SPE 165380 presented at the SPE Western Regional and AAPG Pacific Section Meeting, Joint Technical Conference, Monterey, California, USA, pp 1-13

41. Liang C, Jiang ZX, Yang YT, Wei XJ (2012) Shale lithofacies and reservoir space of the Wufeng-Longmaxi formation Sichuan Basin China. Pet Explor and Dev 39(6):736-743

42. Ross DJK, Bustin MR (2009b) The importance of shale composition and pore structure upon gas storage potential of shale gas reservoirs. Mar Pet Geol 26:916-927

43. Löhr SC, Baruch ET, Hall PA, Kennedy MJ (2015b) Is organic pore development in gas shales influenced by the primary porosity and structure of thermally immature organic matter? Org Geochem $87: 119-132$

44. Xi Z, Tang S, Zhang S, Sun K (2017) Pore structure characteristics of marine-continental transitional shale: a case study in the Qinshui Basin, China. Energ Fuel 31:7854-7866

45. Pan J, Peng C, Wan X, Zheng D, Lv R, Wang K (2017) Pore structure characteristics of coal-bearing organic shale in Yuzhou coalfield, China using low pressure $\mathrm{N}_{2}$ adsorption and FESEM methods. J Pet Sci Eng 153:234-243

46. Li B, Pang $X$, Dong $Y$, Peng J, Gao P, Wu H, Huang C, Shao $X$ (2019) Lithofacies and pore characterization in an 
argillaceous-siliceous-calcareous shale system: a case study of the Shahejie formation in Nanpu Sag, Bohai Bay Basin, China. J Petrol Sci Eng 173:804-819

47. Sing KS, Everett DH, Haul RAW, Mouscou L, Pierotti RA, Rouquerol J, Siemieniewska T (1985b) Reporting physisorption data for gas/ solid systems with special reference to the determination of surface area and porosity. Pure Appl Chem 57(4):603-619

48. Bu HL, Ju YW, Tan JQ, Wang GC, Li XS (2015) Fractal characteristics of pores in non-marine shales from the Huainan coalfield, eastern China. J Nat Gas Sci Eng 24:166-177

49. Zheng Y, Liao Y, Wang Y, Xiong Y, Peng P (2018) Organic geochemical characteristics, mineralogy, petrophysical properties, and shale gas prospects of the Wufeng-Longmaxi shales in Sanquan Town of the Nanchuan district. Chongqing AAPG Bull 102(11):2239-2265
50. Kuila U, Prasad M (2013) Application of nitrogen gas-adsorption technique for characterization of pore structure of mudrocks. Lead Edge 2(32):1478-1485

51. Liang ML, Wang ZX, Gao L, Li CL, Li HJ (2017) Evolution of pore structure in gas shale related to structural deformation. Fuel 197:310-319

Publisher's Note Springer Nature remains neutral with regard to jurisdictional claims in published maps and institutional affiliations. 